\title{
Biogeochemistry of a large and deep tropical lake (Lake Kivu, East Africa: insights from a stable isotope study covering an annual cycle
}

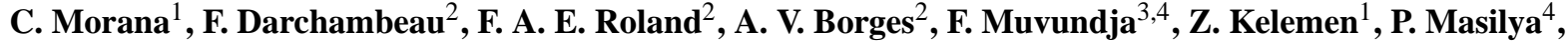 \\ J.-P. Descy ${ }^{3}$, and S. Bouillon ${ }^{1}$ \\ ${ }^{1}$ Department of Earth and Environmental Sciences, Katholieke Universiteit Leuven, Leuven, Belgium \\ ${ }^{2}$ Chemical Oceanography Unit, Université de Liège, Liege, Belgium \\ ${ }^{3}$ Research Unit in Environmental and Evolutionary Biology, Université de Namur, Namur, Belgium \\ ${ }^{4}$ Unité d'Enseignement et de Recherche en Hydrobiologie Appliquée, ISP-Bukavu, Bukavu, \\ Democratic Republic of the Congo
}

Correspondence to: C. Morana (cedric.morana@ees.kuleuven.be)

Received: 14 October 2014 - Published in Biogeosciences Discuss.: 11 December 2014

Revised: 23 July 2015 - Accepted: 9 August 2015 - Published: 19 August 2015

\begin{abstract}
During this study, we investigated the seasonal variability of the concentration and the stable isotope composition of several inorganic and organic matter (OM) reservoirs in the large, oligotrophic and deep tropical Lake Kivu (East Africa). Data were acquired over 1 year at a fortnightly temporal resolution. The $\delta^{13} \mathrm{C}$ signature of the dissolved inorganic carbon (DIC) increased linearly with time during the rainy season, then suddenly decreased during the dry season due to vertical mixing with ${ }^{13} \mathrm{C}$-depleted DIC waters. The $\delta^{13} \mathrm{C}$ signature of the particulate organic carbon pool (POC) revealed the presence of a consistently abundant methanotrophic biomass in the oxycline throughout the year. We also noticed a seasonal shift during the dry season toward higher values in the $\delta^{15} \mathrm{~N}$ of particulate nitrogen $(\mathrm{PN})$ in the mixed layer and $\delta{ }^{15} \mathrm{~N}-\mathrm{PN}$ was significantly related to the contribution of cyanobacteria to the phytoplankton assemblage, suggesting that rainy season conditions could be more favourable to atmospheric nitrogen-fixing cyanobacteria. Finally, zooplankton were slightly enriched in ${ }^{13} \mathrm{C}$ compared to the autochthonous POC pool, and the $\delta^{15} \mathrm{~N}$ signature of zooplankton followed well the seasonal variability in $\delta^{15} \mathrm{~N}-\mathrm{PN}$, consistently $3.0 \pm 1.1 \%$ heavier than the PN pool. Together, $\delta^{13} \mathrm{C}$ and $\delta^{15} \mathrm{~N}$ analysis suggests that zooplankton directly incorporate algal-derived OM in their biomass, and that they rely almost exclusively on this source of OM throughout the
\end{abstract}

year in general agreement with the very low allochthonous OM inputs from rivers in Lake Kivu.

\section{Introduction}

Stable carbon $(\mathrm{C})$ and nitrogen $(\mathrm{N})$ isotope analyses of diverse inorganic and organic components have been successfully used to assess the origin of organic matter (OM) and better understand its cycling in aquatic systems (Lehmann et al., 2004). For instance, an extensive sampling of diverse $\mathrm{C}$ and $\mathrm{N}$ pools over an annual cycle in the Loch Ness showed important seasonal variation of the ${ }^{13} \mathrm{C} /{ }^{12} \mathrm{C}$ and ${ }^{15} \mathrm{~N} /{ }^{14} \mathrm{~N}$ ratios in the crustacean zooplankton biomass, reflecting a diet switch from allochthonous to autochthonous OM sources (Grey et al., 2001). In small humic boreal lakes with permanently anoxic waters, stable $\mathrm{C}$ isotope analyses demonstrated that methanotrophic bacteria could be an important food source for crustacean zooplankton, and hence methane-derived $\mathrm{C}$ contributed to a large fraction of the lake food web (Kankaala et al., 2006). Analyses of the stable C isotope composition of carbonates and OM in sedimentary records of stratified lakes can also provide reliable information about past land use of the catchment (Castañeda et al., 2009), or be used to infer changes in lake productivity and climate (Schelske and Hodell, 1991). However, a detailed un- 
derstanding of the stable isotope dynamics in the water column is a prerequisite for a good interpretation of isotope data from sedimentary archives (Lehmann et al., 2004).

A new paradigm has progressively emerged over the last decade, proposing that freshwaters ecosystems are predominantly net heterotrophic, as respiration of OM exceeds autochthonous photosynthetic production (Del Giorgio et al., 1997; Cole, 1999; Duarte and Prairie, 2005). This concept seems to hold especially true for oligotrophic unproductive ecosystems (Del Giorgio et al., 1997), that are subsidised by substantial inputs of allochthonous OM of terrestrial origin, which support the production of heterotrophic organisms. Net heterotrophy has been recognised as one of the main cause for the net emission of carbon dioxide $\left(\mathrm{CO}_{2}\right)$ from freshwater ecosystems to the atmosphere (Prairie et al., 2002), although there is growing evidence of the contribution from external hydrological $\mathrm{CO}_{2}$ inputs from the catchment (Stets et al., 2009; Finlay et al., 2010; Borges et al., 2014; Marcé et al., 2015). However, the current understanding of the role of inland waters on $\mathrm{CO}_{2}$ emissions could be biased because most observations were obtained in temperate and boreal systems, and mostly in medium-to-small lakes, during open-water (ice-free) periods, but tropical and temperate lakes differed in some fundamental characteristics. Among them, the constantly high temperature and irradiance have strong effects on water column stratification and biological processes (Sarmento, 2012). For instance, primary production in tropical lakes has been recognised to be 2 times higher than in temperate lakes on a given nutrient base (Lewis, 1996). Also, the contribution of dissolved primary production in oligotrophic tropical lakes has been found to substantially more important than in their temperate counterparts (Morana et al., 2014).

East Africa harbours the densest aggregation of large tropical lakes (Bootsma and Hecky, 2003). Some of them are among the largest (lakes Victoria, Tanganyika, Malawi), and deepest lakes in the world (lakes Tanganyika, Malawi, Kivu) and consequently remain stratified all year round. Due to the size and the morphometric traits of the East African Great Lakes, pelagic processes are predominant in these systems, with the microbial food web playing a particularly essential role in $\mathrm{OM}$ transfer between primary producers and higher levels of the food web, and in nutrient cycling (Descy and Sarmento, 2008). Most of them are also characterized by highly productive fisheries that provide an affordable food source to local populations (Descy and Sarmento, 2008). However, while these lakes are potentially important components of biogeochemical cycles at the regional scale (Borges et al., 2011), and significant for local populations from an economic perspective (Kaningini, 1995), the East African Great Lakes are relatively poorly studied, most probably because of their remote location combined with frequent political unrest.

In this study, we present a comprehensive data set covering a full annual cycle, including hydrochemical data and mea- surements of the concentration of dissolved methane $\left(\mathrm{CH}_{4}\right)$ and the concentrations and stable isotope compositions of dissolved inorganic carbon (DIC), dissolved and particulate organic carbon (DOC and POC), particulate nitrogen (PN), and zooplankton. Data were acquired over one full year at a fortnightly/monthly temporal resolution. We aimed to assess the net metabolic status of Lake Kivu, the seasonal and depth variability of sources of OM within the water column, and the relative contribution of autochthonous or allochthonous OM to the zooplankton. To our best knowledge, this is the first detailed study to assess the seasonal dynamics of different OM reservoirs by means of their stable isotope composition in any of the East African Great Lakes. The detailed analysis of the stable isotope composition of diverse organic and inorganic components carried out during this study allowed one to trace the OM dynamics in Lake Kivu over a seasonal cycle, and might be useful to improve the interpretation of sedimentary archives of this large and deep tropical lake.

\section{Material and methods}

Lake Kivu (East Africa) is a large $\left(2370 \mathrm{~km}^{2}\right)$ and deep (maximum depth of $485 \mathrm{~m}$ ) meromictic lake located at the border between the Democratic Republic of the Congo and Rwanda. Its vertical structure consists of an oxic and nutrient-poor mixed layer down to a maximum depth of $70 \mathrm{~m}$, and a permanently anoxic monimolimnion rich in dissolved gases $\mathrm{CCH}_{4}$, and $\mathrm{CO}_{2}$ ) and inorganic nutrients. Seasonal variation of the vertical position of the oxic-anoxic transition is driven by contrasting air humidity and incoming long-wave radiation between rainy (October-May) and dry (June-September) seasons (Thiery et al., 2014). The euphotic zone, defined at the depth at which light is $1 \%$ of surface irradiance, is relatively shallow (annual average: $18 \mathrm{~m}$, Darchambeau et al., 2014).

Sampling was carried out in the southern basin $\left(02^{\circ} 20^{\prime} \mathrm{S}\right.$, $28^{\circ} 58^{\prime}$ E) of Lake Kivu between January 2012 and May 2013 at a monthly or fortnightly time interval. Vertical oxygen $\left(\mathrm{O}_{2}\right)$, temperature and conductivity profiles were obtained with a Hydrolab DS5 multiprobe. The conductivity cell was calibrated with a $1000 \mu \mathrm{S} \mathrm{cm}^{-1}\left(25^{\circ} \mathrm{C}\right)$ Merck standard and the $\mathrm{O}_{2}$ membrane probe was calibrated with humidity saturated ambient air. Water was collected with a $7 \mathrm{~L}$ Niskin bottle (Hydro-Bios) at a depth interval of $5 \mathrm{~m}$ from the lake surface to the bottom of the mixolimnion, at $70 \mathrm{~m}$. Additionally, zooplankton was sampled with a $75 \mathrm{~cm}$ diameter, $55 \mu \mathrm{m}$ mesh plankton net hauled along the whole mixolimnion $(0-$ $70 \mathrm{~m})$.

Samples for $\mathrm{CH}_{4}$ concentrations were collected in $50 \mathrm{~mL}$ glass serum bottles from the Niskin bottle with a tube, left to overflow, poisoned with $100 \mathrm{muL}$ of saturated $\mathrm{HgCl}_{2}$ and sealed with butyl stoppers and aluminium caps. Concentrations of $\mathrm{CH}_{4}$ were measured by headspace technique using gas chromatography (Weiss, 1981) with flame ionisation de- 
tection (SRI 8610C), after creating a $20 \mathrm{~mL}$ headspace with $\mathrm{N}_{2}$ in the glass serum bottles, and then analysed as described by Borges et al. (2011).

Samples for stable $\mathrm{C}$ isotopic composition of dissolved inorganic carbon $\left(\delta^{13} \mathrm{C}\right.$-DIC) were collected by filling water directly from the Niskin bottle $12 \mathrm{~mL}$ headspace vials (Labco Exetainer) without bubbles. Samples were preserved with the addition of $20 \mu \mathrm{L}$ of a saturated $\mathrm{HgCl}_{2}$ solution. Prior to the analysis of $\delta^{13} \mathrm{C}$-DIC, a $2 \mathrm{~mL}$ helium headspace was created, and $100 \mu \mathrm{L}$ of phosphoric acid $\left(\mathrm{H}_{3} \mathrm{PO}_{4}, 99 \%\right)$ was added in the vial in order to convert all inorganic $\mathrm{C}$ species to $\mathrm{CO}_{2}$. After overnight equilibration, $200 \mu \mathrm{L}$ of gas was injected with a gastight syringe into a elemental analyser - isotopic ratio mass spectrometer (EA-IRMS; Thermo FlashHT with Thermo DeltaV Advantage). The obtained data were corrected for isotopic equilibration between dissolved and gaseous $\mathrm{CO}_{2}$ as described in Gillikin and Bouillon (2007). Calibration of $\delta^{13} \mathrm{C}$-DIC measurement was performed with the international certified standards IAEA-CO1 and LSVEC. The reproducibility of $\delta^{13} \mathrm{C}$-DIC measurement was typically better than $\pm 0.2 \%$. Measurements of total alkalinity (TA) were carried out by open-cell titration with $\mathrm{HCl} 0.1 \mathrm{~mol} \mathrm{~L}^{-1}$ according to Gran (1952) on $50 \mathrm{~mL}$ water samples, and data were quality checked with certified reference material obtained from Andrew Dickinson (Scripps Institution of Oceanography, University of California, San Diego, USA). Typical reproducibility of TA measurements was better than $\pm 3 \mu \mathrm{mol} \mathrm{L}-1$. DIC concentration was computed from $\mathrm{pH}$ and TA measurements using the carbonic acid dissociation constants of Millero et al. (2006).

Samples for DOC concentration and stable $\mathrm{C}$ isotopic composition ( $\delta^{13} \mathrm{C}$-DOC) were filtered through pre-flushed $0.2 \mu \mathrm{m}$ syringe filters, kept in $40 \mathrm{~mL}$ borosilicate vials with Teflon-coated screw caps and preserved with $100 \mu \mathrm{L}$ of $\mathrm{H}_{3} \mathrm{PO}_{4}(50 \%)$. Sample analysis was carried out with a IO Analytical Aurora 1030W coupled to an IRMS (Thermo delta V Advantage). Quantification and calibration of DOC and $\delta^{13} \mathrm{C}$-DOC was performed with IAEA-C6 and an internal sucrose standard $\left(\delta^{13} \mathrm{C}=-26.99 \pm 0.04 \%\right.$ ) calibrated against international reference materials.

Samples for POC and particulate nitrogen (PN) concentration and stable carbon and nitrogen isotope composition ( $\delta^{13} \mathrm{C}$-POC; $\left.\delta^{15} \mathrm{~N}-\mathrm{PN}\right)$ were obtained by filtering a known volume of water on pre-combusted (overnight at $450{ }^{\circ} \mathrm{C}$ ) $25 \mathrm{~mm}$ glass fiber filters (Advantec GF-75; $0.3 \mu \mathrm{m}$ ), kept frozen until subsequent processing. The filters were later decarbonated with $\mathrm{HCl}$ fumes for $4 \mathrm{~h}$, dried and packed in silver cups prior to analysis on a EA-IRMS (Thermo FlashHT with Thermo DeltaV Advantage). Calibration of $\delta^{13} \mathrm{C}$-POC, $\delta^{15} \mathrm{~N}-\mathrm{PN}$, POC and PN measurements was performed with acetanilide $\left(\delta^{13} \mathrm{C}=-27.65 \pm 0.05\right.$; $\left.\delta^{15} \mathrm{~N}=1.34 \pm 0.04\right)$ and leucine $\left(\delta^{13} \mathrm{C}=-13.47 \pm 0.07\right.$; $\left.\delta^{15} \mathrm{~N}=0.92 \pm 0.06\right)$ as standards. All standards were internally calibrated against the international standard IAEA-C6 and IAEA-N1. Reproducibility of $\delta^{13} \mathrm{C}-\mathrm{POC}$ and $\delta^{15} \mathrm{~N}-\mathrm{PN}$ measurement was typically better than $\pm 0.2 \%$ and relative standard deviation for POC and PN measurement were always below $5 \%$. Samples for $\delta^{13} \mathrm{C}$ and $\delta^{15} \mathrm{~N}$ of zooplankton were collected on precombusted $25 \mathrm{~mm}$ glass fiber filters (Advantec GF-75; $0.3 \mu \mathrm{m}$ ), and dried. Subsequent preparation of the samples and analysis on the EA-IRMS were performed similarly as described for the $\delta^{13} \mathrm{C}$-POC and $\delta^{15} \mathrm{~N}$ PN samples.

Pigment concentrations were determined by high performance liquid chromatography (HPLC). 2-4 L of water were filtered through Macherey-Nägel GF-5 filter (average retention of $0.7 \mu \mathrm{m})$. Pigment extraction was carried out in $10 \mathrm{~mL}$ of $90 \%$ HPLC grade acetone. After two sonication steps of $15 \mathrm{~min}$ separated by an overnight period at $4{ }^{\circ} \mathrm{C}$, the pigments extracts were stored in $2 \mathrm{~mL}$ amber vials at $-25^{\circ} \mathrm{C}$. HPLC analysis was performed following the gradient elution method described in Wright et al. (1991), with a Waters system comprising photodiode array and fluorescence detectors. Calibration was made using commercial external standards (DHI Lab Products, Denmark). Reproducibility for pigment concentration measurement was better than $7 \%$. Pigment concentrations were processed with the CHEMTAX software (CSIRO Marine Laboratories) using input ratio matrices adapted for freshwater phytoplankton (Descy et al., 2000). Data processing followed a procedure similar to that of Sarmento et al. (2006) in Lake Kivu that allows one to estimate chlorophyll $a$ ( $\mathrm{Chl} a$ ) biomass of cyanobacteria, taking into account variation of pigment ratios with season and depth.

\section{Results}

Analysis of the vertical and seasonal variability of temperature and dissolved $\mathrm{O}_{2}$ concentrations for 18 months allow us to divide the annual cycle into two distinct limnological periods. Rainy season conditions resulted in a thermal stratification within the mixolimnion (October-June) while the dry season was characterized by deeper vertical mixing of the water column down to the upper part of the permanent chemocline at $65 \mathrm{~m}$ (July-September) (Fig. 1a). The vertical position of the oxycline varied seasonally: the oxic-anoxic transition reached its deepest point $(65 \mathrm{~m})$ during the dry season, then became gradually shallower after the re-establishment of the thermal stratification within the mixolimnion at the start of the following rainy season to finally stabilise at approximately $35 \mathrm{~m}$, corresponding to the bottom of the mixed layer during the rainy season (Fig. 1b). The temporal variability of the vertical distribution of $\mathrm{CH}_{4}$ corresponded well with the seasonal variation of the oxycline. The $\mathrm{CH}_{4}$ concentrations were very high in the monimolimnion throughout the year (average at $70 \mathrm{~m}: 356 \pm 69 \mu \mathrm{mol} \mathrm{L}^{-1}, n=24$ ) but sharply decreased at the oxic-anoxic transition, and were 4 orders of mag- 

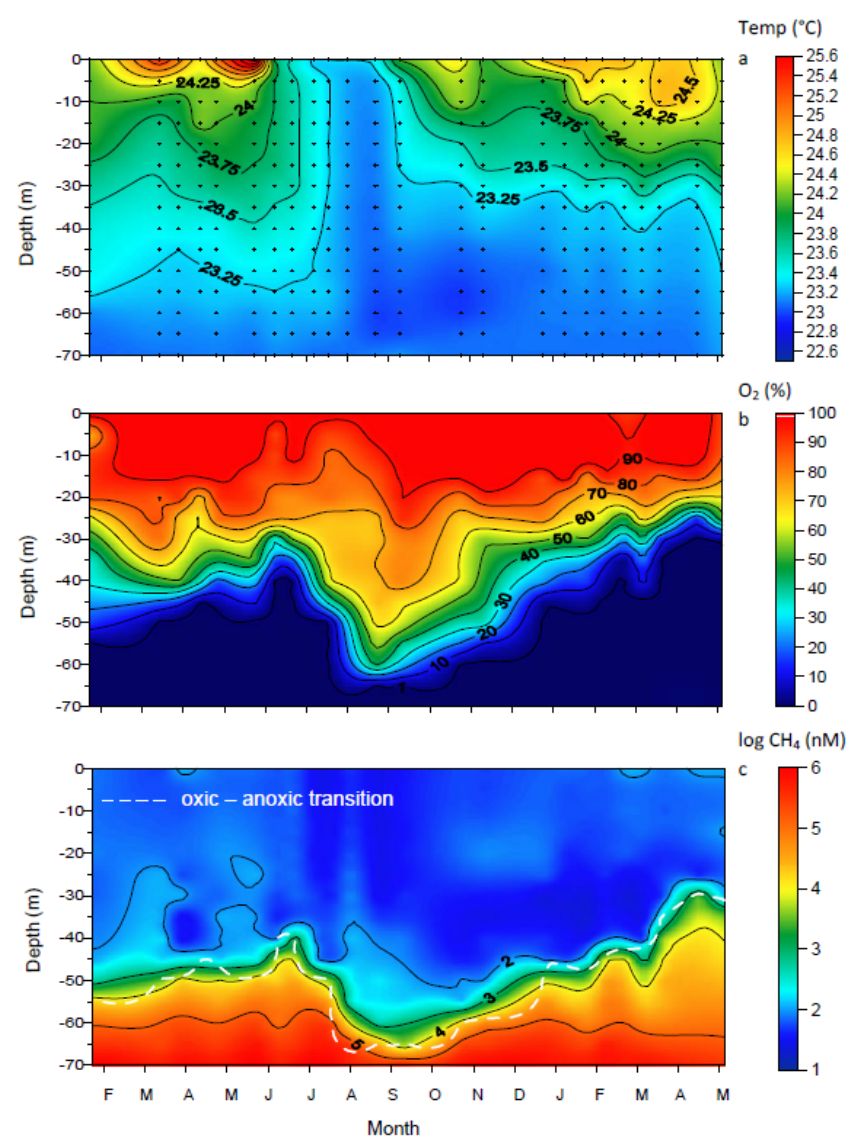

Figure 1. Temporal variability of (a) temperature $\left({ }^{\circ} \mathrm{C}\right)$, (b) oxygen saturation (in percentage), and (c) the log-transformed $\mathrm{CH}_{4}$ concentration $\left(\mathrm{nmol} \mathrm{L}^{-1}\right)$ in the mixolimnion of Lake Kivu, between February 2012 and May 2013. Small crosses in the figure (a) represent each sampling points. The white dashed line represents the vertical position of the oxic-anoxic transition.

nitude lower in surface waters (annual average at $10 \mathrm{~m}$ : $0.062 \pm 0.016 \mu \mathrm{mol} \mathrm{L}^{-1}, n=24$ ) (Fig. 1c).

DIC concentrations in the mixed layer were very high (annual average at $10 \mathrm{~m}: 11.9 \pm 0.2 \mathrm{mmol} \mathrm{L}^{-1}, n=24$ ) and did not show any consistent seasonal pattern (not shown). The $\delta^{13} \mathrm{C}$-DIC values were vertically homogeneous in the mixed layer but gradually decreased in the oxycline to reach minimal values at $70 \mathrm{~m}$ (Fig. $2 \mathrm{a}) \cdot \delta^{13} \mathrm{C}$-DIC values in the mixed layer increased linearly with time during the rainy season $\left(r^{2}=0.79, n=12\right)$, then suddenly decreased at the start of the dry season due to the vertical mixing with ${ }^{13} \mathrm{C}$-depleted DIC from deeper waters (Fig. 2b). Taking into account the analytical precision of $\delta^{13} \mathrm{C}$-DIC measurement (better than $\pm 0.2 \%$ ), this small but linear ${ }^{13} \mathrm{C}$ enrichment with time was significant. The DOC concentration $\left(142 \pm 20 \mu \mathrm{mol} \mathrm{CL} \mathrm{C}^{-1}, n=304\right)$ and $\delta^{13} \mathrm{C}$-DOC signature $(-23.2 \pm 0.4 \%, n=304)$ did not show any consistent variations with depth or time in the mixolimnion over the entire sampling period. A vertical profile performed down
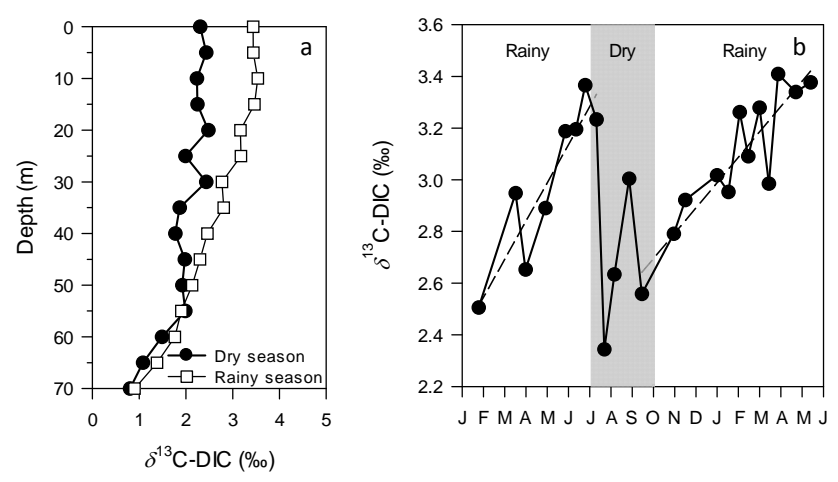

Figure 2. Depth profile of the $\delta^{13} \mathrm{C}$ of the dissolved inorganic carbon (DIC) pool in the mixolimnion during the dry (18 July 2012) and the rainy (20 March 2013) season and (b) temporal variation of the $\delta^{13} \mathrm{C}$-DIC in the mixed layer of Lake Kivu between January 2012 and June 2013.

to the lake floor revealed that the $\delta^{13} \mathrm{C}$-DOC did not vary significantly in the monimolimnion (vertical profile average: $-23.0 \% \circ \pm 0.2, n=18$, Fig. 3); however, an important increase in DOC concentrations was observed starting at $260 \mathrm{~m}$ (Fig. 3), to reach a maximum near the lake floor $(350 \mathrm{~m}$, $301 \mu \mathrm{mol} \mathrm{C} \mathrm{L}{ }^{-1}$ ).

Chlorophyll $a$ concentrations exhibited little variation during the rainy season (average $74 \pm 15 \mathrm{mg} \mathrm{Chl} a \mathrm{~m}^{-2}$, $n=16$ ) but increased significantly during the dry season to reach a maximal value $\left(190 \mathrm{mgChl} a \mathrm{~m}^{-2}\right)$ in September 2012 (Fig. 5b). This increase corresponded with a change in phytoplankton community composition. The relative contribution of cyanobacteria to the phytoplankton assemblage, as assessed from the concentration of marker pigments, was smaller during the dry season than in the preceding ( $t$ test; $p<0.01$, mean $_{\text {jan-jun }}=23.4 \pm 5.5 \%$, mean jul-sep $\left.=9.4 \pm 1.3 \%\right)$ and the following ( $t$ test; $p<0.05$, mean oct-may $=14.6 \pm 3.8 \%$, mean $_{\text {jul-sep }}=9.4 \pm 1.3 \%$ ) rainy seasons (Fig. 5b).

\section{Discussion}

Stable isotope analysis of DIC is a useful tool for understanding the fate of $\mathrm{C}$ in aquatic ecosystems and could provide information on the lake metabolism, defined as the balance between gross primary production and community respiration of OM. Primary producers preferentially incorporate the lighter isotope $\left({ }^{12} \mathrm{C}\right)$ into the biomass with the consequence that the heavier isotope $\left({ }^{13} \mathrm{C}\right)$ accumulates into the DIC pool, whereas mineralisation releases ${ }^{13} \mathrm{C}$-depleted $\mathrm{CO}_{2}$ from the $\mathrm{OM}$ being respired into the DIC pool. Therefore, increasing primary production leads to higher $\delta^{13} \mathrm{C}$-DIC but increasing respiration should tend to decrease $\delta^{13} \mathrm{C}$-DIC (Bade et al., 2004). For instance, several studies conducted in temperate lakes have reported a significant increase in $\delta^{13} \mathrm{C}$-DIC during summer, resulting from primary production (Herczeg, 


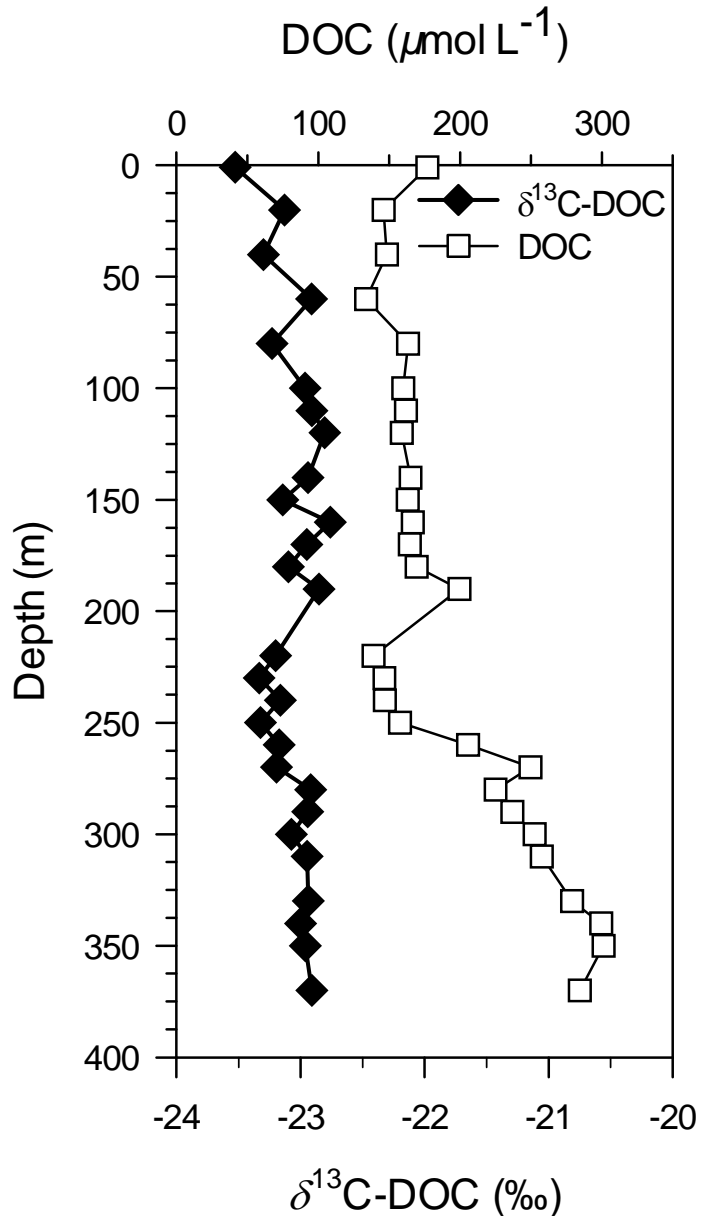

Figure 3. Depth profile from the lake surface to the lake floor of the dissolved organic carbon (DOC) concentration $\left(\mu \mathrm{mol} \mathrm{L}{ }^{-1}\right)$ and the $\delta^{13} \mathrm{C}$ signature of the DOC pool, in September 2012. The white dashed line represents the vertical position of the oxic-anoxic transition.

1987; Hollander and McKenzie, 1991). In Lake Kivu, the $\delta^{13} \mathrm{C}$-DIC increased linearly with time during the stratified rainy season, deviating gradually from the $\delta^{13} \mathrm{C}$-DIC value expected if the DIC pool was at equilibrium with the atmospheric $\mathrm{CO}_{2}(\sim 0.49 \%)$. It appears unlikely that this linear isotopic enrichment of the DIC pool is due to physical processes: the $\delta^{13} \mathrm{C}$-DIC signature of the DIC input from the inflowing rivers (Borges et al., 2014) and deep waters (Fig. 3a) was indeed lower than the measured $\delta^{13} \mathrm{C}$-DIC in the mixed layer. Therefore, biological processes (i.e. photosynthetic $\mathrm{CO}_{2}$ uptake) are likely responsible of the isotopic enrichment of the DIC pool observed during the stratified rainy season. Nevertheless, a small decrease in $\delta^{13} \mathrm{C}$-DIC was recorded at the beginning of the dry season (early in July 2012), but was concomitant with the characteristic deepening of the mixed layer observed during the dry season. As the depth profile of $\delta^{13} \mathrm{C}$-DIC revealed that the DIC pool was isotopically lighter in the bottom of the mixolimnion,
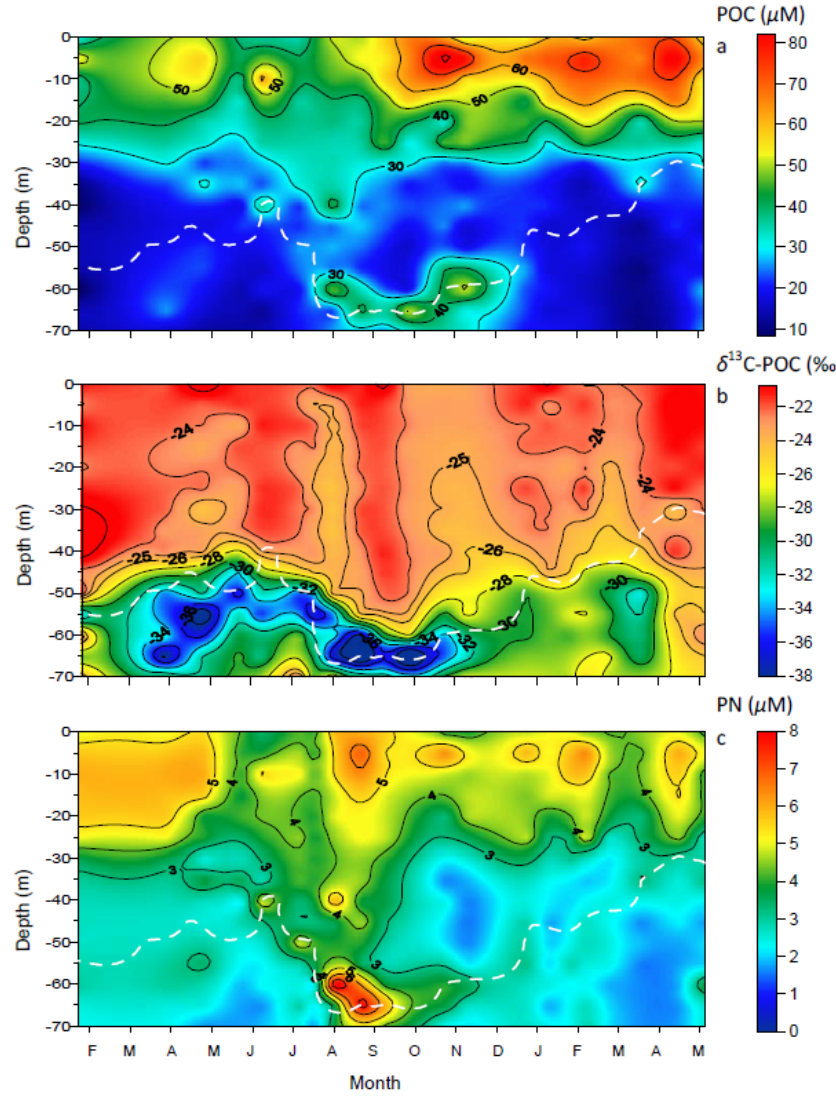

Figure 4. Temporal variability of (a) the particulate organic carbon (POC) concentration $(\mu \mathrm{mol} \mathrm{L}-1)$, (b) the $\delta^{13} \mathrm{C}$ signature of the POC pool, and (c) the particulate nitrogen $(\mathrm{PN})$ concentration $\left(\mu \mathrm{mol} \mathrm{L}{ }^{-1}\right)$ in the mixolimnion of Lake Kivu, between February 2012 and May 2013.

the measurement of lower $\delta^{13} \mathrm{C}$-DIC values during the dry season could have resulted from the seasonal vertical mixing of surface waters with bottom waters containing relatively ${ }^{13} \mathrm{C}$-depleted DIC.

Overall, the data suggest that the input of DIC originating from the monimolimnion during the dry season had a strong influence on $\delta^{13} \mathrm{C}$-DIC in the mixolimnion, but the seasonal variability of $\delta^{13} \mathrm{C}$-DIC observed in the mixed layer holds information on biological processes. The gradual increase with time of the $\delta^{13} \mathrm{C}$-DIC in the mixed layer supports the conclusions of other studies carried out in Lake Kivu (Morana et al., 2014; Borges et al., 2014) which showed, based on a detailed DIC and DI ${ }^{13} \mathrm{C}$ mass balance approach and several microbial processes measurements, that photosynthetic $\mathrm{CO}_{2}$ fixation should exceed the respiration of OM. Indeed, in Lake Kivu, riverine inputs of allochthonous OM from the catchment (0.7-3.3 mmol m ${ }^{-2} \mathrm{~d}^{-1}$, Borges et al., 2014) are minimal compared to primary production $\left(49 \mathrm{mmol} \mathrm{m}^{-2} \mathrm{~d}^{-1}\right.$; Darchambeau et al., 2014) and the export of organic carbon to the monimolimnion $\left(9.4 \mathrm{mmol} \mathrm{m}^{-2} \mathrm{~d}^{-1}\right)$ reported by Pasche et al. (2010). The outflow of organic carbon through 

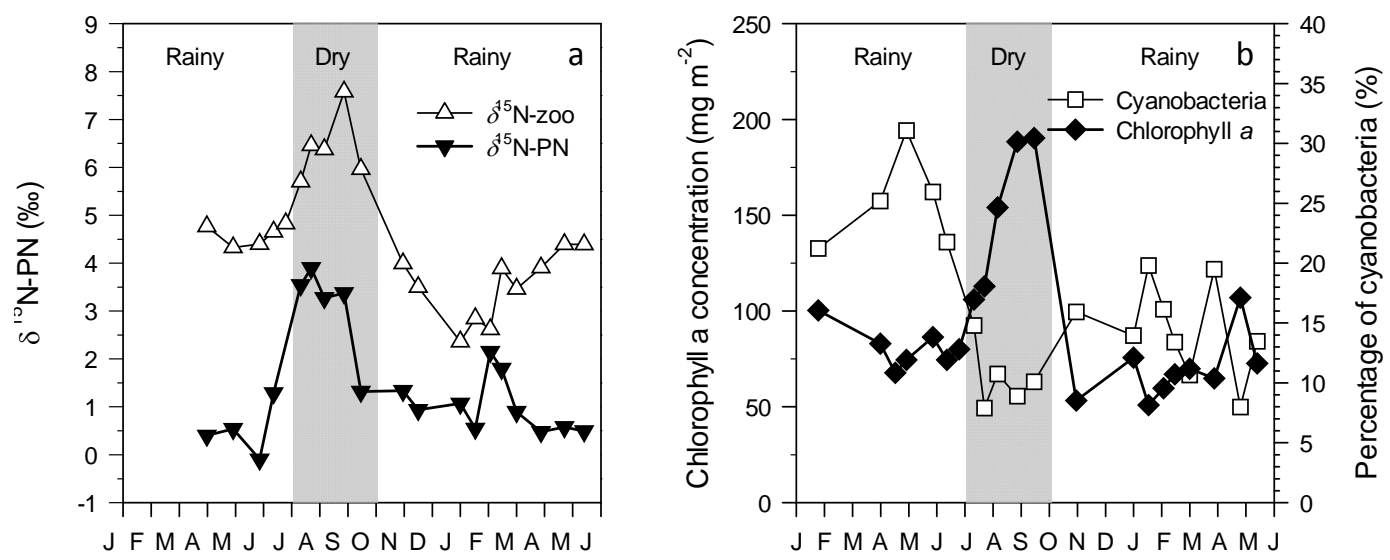

Figure 5. Temporal variability of (a) the $\delta^{15} \mathrm{~N}$ signature of the particulate nitrogen (PN) pool and zooplankton in the mixed layer, and (b) the chlorophyll $a$ concentration $\left(\mathrm{mg} \mathrm{m}^{-2}\right.$ ) and the relative contribution of cyanobacteria to the phytoplankton assemblage (percentage of biomass) in the mixolimnion, assessed from pigment analyses, between February 2012 and May 2013.

the Ruzizi River is also relatively low and was computed to be $0.6 \mathrm{mmol} \mathrm{m}^{-2} \mathrm{~d}^{-1}$ (this study) based on the long-term discharge average of Ruzizi $\left(83.2 \mathrm{~m}^{3} \mathrm{~s}^{-1}\right.$, Borges et al., 2014), the average POC and DOC in surface waters $(0.052$ and $0.142 \mathrm{mmol} \mathrm{L}^{-1}$, this study). It implies that the outputs of $\mathrm{OM}\left(9.4+0.7=10.1 \mathrm{mmol} \mathrm{m}^{-2} \mathrm{~d}^{-1}\right)$ are higher than the inputs of OM from the catchment $\left(0.7-3.3 \mathrm{mmol} \mathrm{m}^{-2} \mathrm{~d}^{-1}\right)$ suggesting a net autotrophic status of Lake Kivu.

However, these results contradict the commonly held view that oligotrophic lacustrine and marine systems tend to be net heterotrophic (Del Giorgio et al., 1997; Cole, 1999). Net heterotrophy implies that heterotrophic prokaryotes rely on a substantial amount of allochthonous OM; however, in Lake Kivu, riverine inputs of allochthonous $\mathrm{OM}$ from the catchment $\left(0.7-3.3 \mathrm{mmol} \mathrm{m}^{-2} \mathrm{~d}^{-1}\right.$, Borges et al., 2014) are minimal. Indeed, the magnitude of allochthonous OM inputs relative to phytoplankton production depends strongly on the catchment to surface area ratio (Urban et al., 2005), that is particularly low (2.2) in Lake Kivu. Therefore, Lake Kivu is relatively poor in organic C, with DOC concentrations of $\sim 0.15 \mathrm{mmol} \mathrm{L}^{-1}$ in contrast to smaller boreal humic lakes which show DOC concentrations of on average $\sim 1 \mathrm{mmol} \mathrm{L}^{-1}$ (Sobek et al., 2007), and with values up to $\sim 4.5 \mathrm{mmol} \mathrm{L}^{-1}$ (Weyhenmeyer and Karlsson, 2009). Humic substances are usually low-quality substrates for bacterial growth (Castillo et al., 2003), but limit primary production by absorbing incoming light. Hence, heterotrophic production in the photic zone of humic lakes usually exceeds phytoplankton production and DOC concentrations, despite the low substrate quality of humic substances, have been found to be a good predictor of the metabolic status of lakes in the boreal region, with a prevalence of net heterotrophy in organic-rich lakes (Jansson et al., 2000). However, low allochthonous OM inputs and low DOC concentration do not necessary cause a system to be net autotrophic. For instance, Lake Superior, subsidised by a simi- lar amount of allochthonous OM $\left(\sim 3 \mathrm{mmol} \mathrm{m}^{-2} \mathrm{~d}^{-1}\right)$, has a lower catchment-to-surface area ratio (1.6), and its water has a DOC concentration even lower than in Lake Kivu $\left(\sim 0.1 \mathrm{mmol} \mathrm{L}^{-1}\right)$. However, it has been found to be net heterotrophic despite the limited allochthonous OM inputs (Urban et al., 2005). Lake Superior, as the majority of the lakes of the world, is holomictic, meaning that the mixing of its water column can seasonally reach the lake floor, and a substantial amount of sediments, including OM, could then be resuspended during these mixing events and hence re-exposed to microbial mineralisation in well-oxygenated waters (Meyers and Eadie, 1993; Cotner, 2000; Urban et al., 2005). The resuspension of bottom sediments could be important in the ecological functioning of these systems. In contrast, Lake Kivu, as other East African Great Lakes such as Tanganyika and Malawi, are particularly deep meromictic lakes, so that their water column is characterized by an almost complete decoupling between the surface and deep waters, preventing any resuspended bottom sediment to reach the surface waters in this system. In consequence, the coupling between the phytoplankton production of DOC and its heterotrophic consumption by prokaryotes in the clear, nutrient-depleted waters of Lake Kivu was found to be high throughout the year (Morana et al., 2014).

Besides morphometrical features, the net autotrophic status of Lake Kivu might also be related to general latitudinal and climatic patterns. Due to the warmer temperature in the tropics, phytoplankton production is comparatively higher in the East African Great Lakes compared with the Laurentian Great Lakes, despite similar phytoplankton abundance (Bootsma and Hecky, 2003). Alin and Johnson (2007) examined phytoplankton primary production and $\mathrm{CO}_{2}$ emissions to the atmosphere fluxes in large lakes of world $\left(>500 \mathrm{~km}^{2}\right)$. At the global scale, they found a statistically significant increase of the areal phytoplankton production in large lakes with the mean annual water temperature and the insolation; 
as a consequence, a significant decrease of phytoplankton production with latitude. Also, they report a significant decrease of the $\mathrm{CO}_{2}$ emissions to the atmosphere with the mean annual water temperature and therefore an increase of the $\mathrm{CO}_{2}$ emission with the latitude. According to their estimations, less than $20 \%$ of the phytoplankton primary production is sufficient to balance the carbon loss through $\mathrm{CO}_{2}$ evasion and OM burial in sediments in large lakes located between the equator and the latitude $30^{\circ}$, but the $\mathrm{CO}_{2}$ emission and $\mathrm{OM}$ accumulation in sediments exceed the phytoplankton primary production in systems located at latitude higher than $40^{\circ}$ (Alin and Johnson, 2007). Overall, in morphometrically comparable systems, this global analysis suggests a trend from autotrophic to increasingly heterotrophic conditions with increasing latitude and decreasing mean annual water temperature and insolation (Alin and Johnson, 2007). Therefore, our study supports the view that paradigms established with data gathered in comparatively small temperate and boreal lakes may not directly apply to larger, tropical lakes (Bootsma and Hecky, 2003). It also highlights the need to consider the unique limnological characteristics of a vast region of the world that harbours $16 \%$ of the total surface of lakes (Lehner and Döll, 2004), and account for $50 \%$ of the global inputs of OM from continental waters to the oceans (Ludwig et al., 1996).

The $\delta^{13} \mathrm{C}$ data indicate a difference in the origins of the POC and DOC pools in the mixed layer. Indeed, the $\delta^{13} \mathrm{C}$ DOC showed very little variation and appeared to be vertically and temporally uncoupled from the POC pool in the mixed layer (Fig. 6). A recent study (Morana et al., 2014) demonstrated that phytoplankton extracellular release of DOC is relatively high in Lake Kivu, and the fresh and labile autochthonous DOC produced by cell lysis, grazing or phytoplankton excretion, which reflects the $\delta^{13} \mathrm{C}$ signature of POC, is quickly mineralised by heterotrophic bacteria. Therefore, it appears that the freshly produced autochthonous DOC contributes less than $1 \%$ of the total DOC pool (Morana et al., 2014), and as the standing stock of phytoplankton-derived DOC seems very small, it can be hypothesised that the bulk DOC pool is mainly composed of older, more refractory compounds that reach the mixed layer through vertical advective and diffusive fluxes. Indeed, the $\delta^{13} \mathrm{C}$ signature of the DOC in the monimolimnion (80$370 \mathrm{~m},-23.0 \pm 0.2 \%$ o, $n=24)$ did not differ from the $\delta^{13} \mathrm{C}$ DOC in the mixolimnion $(0-70 \mathrm{~m},-23.2 \pm 0.2 \%, n=5)$, suggesting that they share the same origin (Fig. 4).

The concentration of the POC pool varied largely with depth, being the highest in the 0-20 m layer, i.e. roughly the euphotic zone. However, during the dry season, POC concentrations were almost as high in the oxycline than in surface waters. High POC concentrations in deep waters have frequently been observed in lakes, usually as a result of the resuspension of bottom sediments near the lake floor or the accumulation of sedimenting material in density gradients (Hawley and Lee, 1999). However, in the deep Lake Kivu,

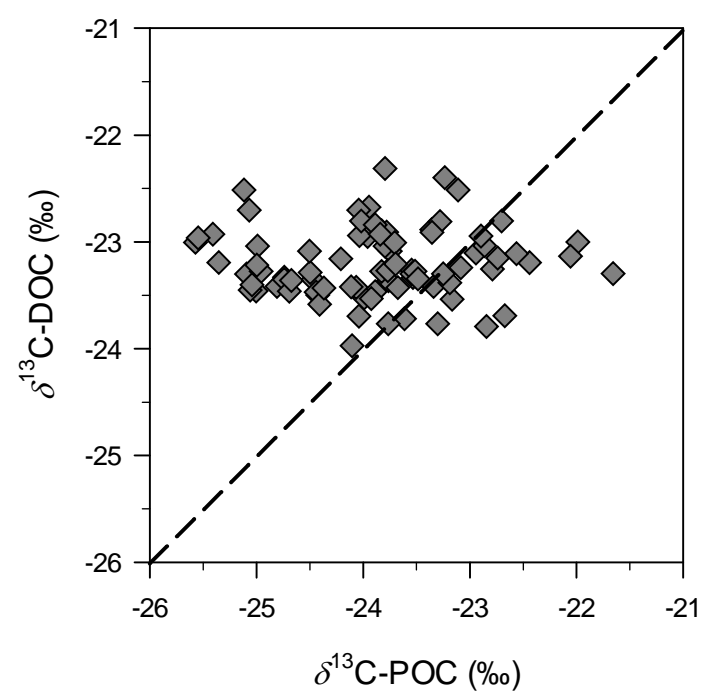

Figure 6. Relationship between the $\delta^{13} \mathrm{C}$ signature of the particulate and dissolved organic carbon pool (POC and DOC, respectively) in the mixed layer.

this maximum POC zone is located approximately $300 \mathrm{~m}$ above the lake floor and is characterized by a strong depletion in ${ }^{13} \mathrm{C}$ of the POC pool. While DIC is probably the major $\mathrm{C}$ source of the POC pool in the mixed layer, the important decrease of $\delta^{13} \mathrm{C}$-POC values observed in the oxycline suggests that another ${ }^{13} \mathrm{C}$-depleted $\mathrm{C}$ source was actively incorporated into the biomass at the bottom of the mixolimnion. Slight depletion in ${ }^{13} \mathrm{C}$ of the POC pool in oxyclines, such as in the Black Sea, has sometimes been interpreted as a result of to the heterotrophic mineralisation of the sedimenting OM (Çoban-Yıldız et al., 2006), but it seems unlikely that, in Lake Kivu, heterotrophic processes could have caused an abrupt excursion of $\delta^{13} \mathrm{C}$-POC to values as low as $-41.6 \%$ (65 m, 22 August 2012). Such large isotopic depletion of the POC pool in the water column has been reported by Blees et al. (2014), who measured $\delta^{13} \mathrm{C}$ POC as low as $-49 \%$ in Lake Lugano, and it was related to high methanotrophic activity. In Lake $\mathrm{Kivu}, \mathrm{CH}_{4}$ concentrations were found to decrease sharply with decreasing depth at the oxic-anoxic transition (Borges et al., 2011), and the dissolved $\mathrm{CH}_{4}$ that reached the oxycline via turbulent diffusivity and vertical advection (Schmid et al., 2005) is known to be isotopically light, with a $\delta^{13} \mathrm{C}$ signature of approximately $-60 \%$ (Pasche et al., 2011; Morana et al., 2015). Therefore, the vertical patterns in $\mathrm{CH}_{4}$ concentrations and $\delta^{13} \mathrm{C}$-POC values observed during this study suggest that a substantial part of $\mathrm{CH}_{4}$ was consumed and incorporated into the microbial biomass in the oxycline. Indeed, experiments carried out in Lake Kivu in February 2012 and September 2012 showed that microbial $\mathrm{CH}_{4}$ oxidation was significant in the oxycline, and phospholipid fatty acid analysis revealed high abundance of methanotrophic bacteria of type I at the same depths (Morana et al., 2015). With es- 
timates of the isotope fractionation factor during microbial $\mathrm{CH}_{4}$ oxidation (1.016, Morana et al., 2015), and of the $\delta^{13} \mathrm{C}$ $\mathrm{CH}_{4}$ at each sampling point, it is possible to estimate the theoretical $\delta^{13} \mathrm{C}$ signature of methanotrophic organisms at each depth. Note that the $\delta^{13} \mathrm{C}_{-}-\mathrm{CH}_{4}$ was not directly measured during this study but a very strong linear correlation between the log-transformed $\mathrm{CH}_{4}$ concentrations and $\delta^{13} \mathrm{C}$ $\mathrm{CH}_{4}$ was found along vertical profiles performed in February and September 2012 in Lake Kivu $\left(\delta^{13} \mathrm{C}-\mathrm{CH}_{4}=-7.911\right.$ $\log \left(\mathrm{CH}_{4}\right)-13.027 ; r^{2}=0.87, n=34$; Morana et al., 2015). Hence the $\delta^{13} \mathrm{C}^{-\mathrm{CH}_{4}}$ at each sampling point between January 2012 and May 2013 can be approximated from the measured $\mathrm{CH}_{4}$ concentrations using this empirical relationship. Then, a simple isotope mixing model with the calculated $\delta^{13} \mathrm{C}$ signature of methanotrophs and the average $\delta^{13} \mathrm{C}-\mathrm{POC}$ in the mixed layer as end-members allows us to determine the contribution of $\mathrm{CH}_{4}$-derived $\mathrm{C}$ to $\mathrm{POC}$ at each sampling depth. It appears that $4.4 \pm 1.9 \%(n=13)$ and $6.4 \pm 1.6 \%(n=5)$ of the depth-integrated POC pool in the mixolimnion was derived from $\mathrm{CH}_{4}$ incorporation into the biomass during the rainy and dry season, respectively, and these percentages did not significantly differ between seasons (two-tailed $t$ test, $p=0.055)$. Nevertheless, the low $\delta^{13} \mathrm{C}$ signatures measured locally in the oxycline indicate that the contribution of $\mathrm{CH}_{4}$ derived $\mathrm{C}$ could be episodically as high as $50 \%(65 \mathrm{~m}, 22$ August 2012). We hypothesise that microbial $\mathrm{CH}_{4}$ oxidation could play an important role in the ecological functioning of Lake Kivu. Along with heterotrophic mineralisation of the sinking OM, and presumably other chemoautotrophic processes occurring in the oxycline such as nitrification (Llirós et al., 2010), $\mathrm{CH}_{4}$ oxidation contributed substantially to $\mathrm{O}_{2}$ consumption in the water column and was partly responsible for the seasonal uplift of the oxycline observed after the re-establishment of the thermal stratification during the rainy season. Furthermore, the methanotrophs in the oxycline actively participated in the uptake of dissolved inorganic phosphorus (DIP), and hence exerted an indirect control on phytoplankton by constantly limiting the vertical DIP flux to the illuminated surface waters (Haberyan and Hecky, 1987). Indeed, phytoplankton in Lake Kivu suffer from a severe P limitation throughout the year as pointed out by the relatively high sestonic C: $\mathrm{P}$ ratio (256 \pm 75 ; Sarmento et al., 2009; Darchambeau et al., 2014).

The $\delta^{15} \mathrm{~N}$ signature of the autochthonous OM in the mixed layer of Lake Kivu oscillated around 0\%o during the rainy season in Lake Kivu but was significantly higher during the dry season $\left(3-4 \%\right.$ ). Also, the $\delta^{15} \mathrm{~N}-\mathrm{PN}$ in the mixed layer correlated negatively with the proportion of cyanobacteria in waters (Fig. 7, Pearson's $r:-0.65, p=0.004, n=17$ ). This pattern may highlight the seasonal importance of $\mathrm{N}_{2}$ fixing cyanobacteria in Lake Kivu during the rainy season. Indeed, the $\delta^{15} \mathrm{~N}$ signature of atmospheric $\mathrm{N}_{2}$ is close to $0 \%$, and isotope fractionation during cyanobacterial $\mathrm{N}_{2}$-fixation is known to be small (Fogel and Cifuentes, 1993). Several studies carried out in marine (Pacific Ocean and Gulf of

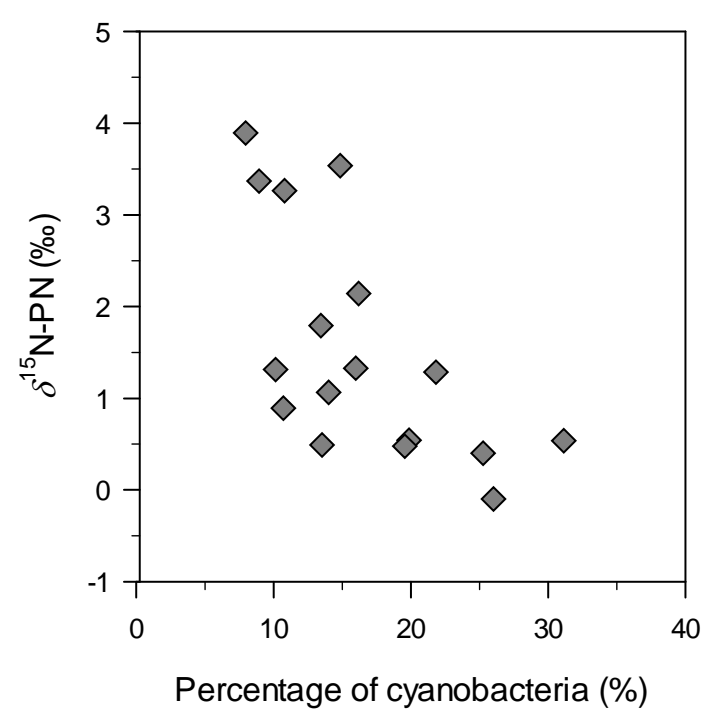

Figure 7. Relationship between the relative contribution of cyanobacteria to the phytoplankton assemblage (percentage of biomass) and the $\delta^{15} \mathrm{~N}$ signature of the particulate nitrogen pool in the mixed layer.

Mexico) and lacustrine (Lake Lugano) systems have shown that $\delta^{15} \mathrm{~N}$-PN varied between -2 and $+1 \%$ o when $\mathrm{N}_{2}$-fixing cyanobacteria were dominating the phytoplankton assemblage (Wada and Hattori, 1976; Macko et al., 1987; Lehmann et al., 2004). Moreover, a good relationship between the $\delta^{15} \mathrm{~N}-\mathrm{PN}$ and the abundance of $\mathrm{N}_{2}$-fixing cyanobacteria has already been reported for others systems, such as coastal lagoons (Lesutienè et al., 2014). In Lake Victoria, biological $\mathrm{N}_{2}$ fixation has been identified as having the largest input of $\mathrm{N}$, exceeding atmospheric deposition and river inputs, and $\mathrm{N}_{2}$ fixation has been found to increase with light availability (Mugidde et al., 2003). This suggests that during the rainy season, when thermal stratification of the mixolimnion leads to reduced nitrogen supply combined with exposure to high light levels, $\mathrm{N}_{2}$-fixing cyanobacteria have a competitive advantage which may explain their seasonally higher contribution to the autochthonous OM pool (Sarmento et al., 2006). Indeed, the significantly higher molar $\mathrm{C}: \mathrm{N}$ ratio during the rainy season than the dry season indicates that $\mathrm{N}$ limitation in the mixed layer was stronger during the rainy season (this study, Sarmento et al., 2009). By contrast, the deepening of the mixed layer during the dry season leads to increased nutrient input and reduced light availability that favours alternative phytoplankton strategies (Hecky and Kling, 1987, 2006; Sarmento et al., 2006; Darchambeau et al., 2014), and consequently the proportion $\mathrm{N}_{2}$-fixing cyanobacteria decreases. A similar seasonal pattern of $\mathrm{N}_{2}$ fixation was reported in Lake Victoria by Mugidde et al. (2003). In contrast with the rather constant $\delta^{13} \mathrm{C}$ signature of zooplankton $(-22.9 \pm 0.8 \%)$, the $\delta^{15} \mathrm{~N}$ analysis revealed that the $\delta^{15} \mathrm{~N}$ of zooplankton varied significantly, following well the sea- 
sonal change in $\delta^{15} \mathrm{~N}-\mathrm{PN}$ in the mixed layer. The difference between $\delta^{15} \mathrm{~N}$-zooplankton and $\delta^{15} \mathrm{~N}-\mathrm{PN}\left(\Delta^{15} \mathrm{~N}\right.$ Zoo-PN $)$ was on average $3.2 \pm 1.0 \%$ o throughout the year while it was on average enriched in ${ }^{13} \mathrm{C}\left(\Delta^{13} \mathrm{C}_{\text {Zoo-POC }}\right)$ by $0.9 \pm 0.8 \%$ o. In nature, comparison of the $\delta^{15} \mathrm{~N}$ signature of consumers and their diet indicates that the $\delta^{15} \mathrm{~N}$ value increases consistently with the trophic level, because of the preferential excretion of the isotopically lighter ${ }^{14} \mathrm{~N}$ (Montoya et al., 2002). However, the $\mathrm{C}$ isotope fractionation between consumers and diet is usually considered to be less than $1 \%$ o (Sirevåg et al., 1977). The constant $\Delta{ }^{15} \mathrm{~N}_{\mathrm{Zoo}-\mathrm{PN}}$ value found in Lake Kivu is within the range of trophic level enrichment between algae and Daphnia magna ( $\sim 2$ to 5\%) estimated in laboratory experiment (Adams and Sterner, 2000), and very close to the cross-system trophic enrichment value $(3.4 \pm 1.0 \%$ o) proposed by Post (2002). Together with the slight enrichment in ${ }^{13} \mathrm{C}$ compared with the autochthonous POC pool, $\delta^{13} \mathrm{C}$ and $\delta^{15} \mathrm{~N}$ analysis suggests that zooplankton directly incorporate phytoplankton-derived OM in their biomass (Masilya, 2011), and they rely almost exclusively on this source of OM throughout the year. This is in general agreement with the very low allochthonous OM inputs from rivers in Lake Kivu (Borges et al., 2014).

In conclusion, stable isotope data revealed large seasonal variability in the $\delta^{15} \mathrm{~N}$ signature of the PN pool, most likely related to changes in the phytoplankton assemblage and to $\mathrm{N}_{2}$-fixation. Contradicting the common observation that oligotrophic aquatic ecosystems tend to be net heterotrophic, the seasonality of $\delta^{13} \mathrm{C}$-DIC supports the view that the mixed layer of Lake Kivu is net autotrophic, as demonstrated by Borges et al. (2014) based on DIC and DI ${ }^{13} \mathrm{C}$ mass balance considerations. The $\delta^{13} \mathrm{C}$-POC showed an important variation with depth due to the abundance of methanotrophic bacteria in the oxycline that fixed the lighter $\mathrm{CH}_{4}$-derived $\mathrm{C}$ into their biomass. The $\delta^{13} \mathrm{C}$-POC and $\delta^{13} \mathrm{C}$-DOC appeared to be uncoupled vertically and temporally, which could indicate that most of the DOC pool was composed of relatively refractory compounds. Finally, the $\delta^{13} \mathrm{C}$ of zooplankton mirrored the $\delta^{13} \mathrm{C}$ signature of the autochthonous POC pool, and its $\delta^{15} \mathrm{~N}$ signature followed the seasonal variability of the $\delta^{15} \mathrm{~N}-\mathrm{PN}$ pool in good agreement with the expected consumer-diet isotope fractionation. This suggests that zooplankton rely throughout the year on phytoplankton-derived biomass as a organic $\mathrm{C}$ source.

Acknowledgements. We are grateful to Boniface Kaningini, Pascal Isumbisho (Institut Supérieur Pédagogique, Bukavu, DRC) for logistical support during the cruises, to Georges Alunga and the staff of the Unité d'Enseignement et de Recherche en Hydrobiologie Appliquée (UERHA - ISP Bukavu), who carried out the field sampling in DRC. We are also grateful to MarcVincent Commarieu, who carried out the TA measurements in the University of Liège, to Stephan Hoornaert, who carried out part of the $\mathrm{CH}_{4}$ measurements and to Bruno Leporcq, who carried out the pigment analysis in the University of Namur. We thank the two anonymous reviewers and the editor S. W. A. Naqvi for their comments and suggestions, which significantly contributed to improving the manuscript. This work was funded by the EAGLES (East African Great Lake Ecosystem Sensitivity to Changes, $\mathrm{SD} / \mathrm{AR} / 02 \mathrm{~A}$ ) project from the Belgian Federal Science Policy Office (BELSPO, Belgium) and contributes to the European Research Council (ERC) starting grant project AFRIVAL (African river basins: Catchment-scale carbon fluxes and transformations, 240002). Alberto V. Borges is a senior research associate at the FNRS (Belgium).

Edited by: S. W. A. Naqvi

\section{References}

Adams, T. S. and Sterner, R. W.: The effect of dietary nitrogen content on trophic level ${ }^{15} \mathrm{~N}$ enrichment, Limnol. Oceanogr., 45 , 601-607, 2000.

Alin, S. R. and Johnson, T. C.: Carbon cycling in large lakes of the world: A synthesis of production, burial, and lake-atmosphere exchange estimates, Global Biogeochem. Cy., 21, GB3002, doi:10.1029/2006GB002881, 2007.

Bade, D. L., Carpenter, S. R., Cole, J. J., Hanson, P. C., and Hesslein, R. H.: Controls of $\delta^{13} \mathrm{C}$-DIC in lakes: Geochemistry, lake metabolism, and morphometry, Limnol. Oceanogr., 49, 1160-1172, 2004.

Blees, J., Niemann, H., Wenk, C. B., Zopfi, J., Schubert, C. J., Kirf, M. K., Veronesi, M. L., Hitz, C., and Lehmann, M. F.: Micro-aerobic bacterial methane oxidation in the chemocline and anoxic water column of deep south-Alpine Lake Lugano (Switzerland), Limnol. Oceanogr., 59, 311-324, 2014.

Bootsma, H. A. and Hecky, R. E.: A comparative introduction to the biology and limnology of the African Great Lakes, J. Great Lakes Res., 29, 3-18, 2003.

Borges, A. V., Abril, G., Delille, B., Descy, J. P., and Darchambeau, F.: Diffusive methane emissions to the atmosphere from Lake Kivu (Eastern Africa), J. Geophys. Res., 116, G03032, doi:10.1029/2011JG001673, 2011.

Borges, A. V., Morana, C., Bouillon, S., Servais, P., Descy, J.-P., and Darchambeau, F.: Carbon cycling of Lake Kivu (East Africa) : Net autotrophy in the epilimnion and emission of $\mathrm{CO}_{2}$ to the atmosphere sustained by geogenic inputs, PLoS ONE, 9, e109500, doi:10.1371/journal.pone.0109500, 2014.

Castañeda, I. S., Werne, J. P., Johnson, T. C., and Filley, T. R.: Late Quaternary vegetation history of southeast Africa: the molecular isotopic record from Lake Malawi. Palaeogeography, Palaeoclimatology, Palaeoecology, 275, 100-112, 2009.

Castillo, M. M., Kling, G. W., and Allan. J. D.: Bottom-up controls on bacterial production in tropical lowland rivers, Limnol. Oceanogr., 48, 1466-1475, 2003.

Çoban-Yıldız, Y., Altabet, M. A., Yılmaz, A., and Tuğrul, S.: Carbon and nitrogen isotopic ratios of suspended particulate organic matter (SPOM) in the Black Sea water column, Deep-Sea Res. Pt. II, 53, 1875-1892, 2006.

Cole, J. J.: Aquatic microbiology for ecosystem scientists: new and recycled paradigms in ecological microbiology, Ecosystems, 2, 215-225, 1999. 
Cotner, J. B., Johengen, T. H., and Biddanda, B. A.: Intense winter heterotrophic production stimulated by benthic resuspension, Limnol. Oceanogr., 45, 1672-1676, 2000.

Darchambeau, F., Sarmento, H., and Descy, J.-P.: Primary production in a tropical large lake: The role of phytoplankton composition, Sci. Total Environ., 473, 178-188, 2014.

Del Giorgio, P. A., Cole, J. J., and Cimbleris, A.: Respiration rates in bacteria exceed phytoplankton production in unproductive aquatic systems, Nature, 385, 148-151, 1997.

Descy, J.-P. and Sarmento, H.: Microorganisms of the East African Great Lakes and their response to environmental changes, Freshwater Reviews, 1, 59-73, 2008.

Descy, J.-P., Higgins, H. W., Mackey, D. J., Hurley, J. P., and Frost, T. M.: Pigment ratios and phytoplankton assessment in northern Wisconsin lakes, J. Phycol., 36, 274-286, 2000.

Duarte, C. M. and Prairie, Y. T.: Prevalence of heterotrophy and atmospheric $\mathrm{CO}_{2}$ emissions from aquatic ecosystems, Ecosystems, 8, 862-870, 2005.

Finlay, K., Leavitt, P. R., Patoine, A., and Wissel, B.: Magnitudes and controls of organic and inorganic carbon flux through a chain of hardwater lakes on the northern Great Plains, Limnol. Oceanogr., 55, 1551-1564, 2010.

Fogel, M. L. and Cifuentes, L. A.: Isotope fractionation during primary production, 73-98, in: Organic geochemistry, edited by: Engel, M. H. and Macko, S. A., Plenum Press, New York, 1993.

Gillikin, D. P. and Bouillon, S.: Determination of $\delta^{18} \mathrm{O}$ of water and $\delta^{13} \mathrm{C}$ of dissolved inorganic carbon using a simple modification of an elemental analyser-isotope ratio mass spectrometer: an evaluation, Rapid Commun. Mass Sp., 21, 1475-1478, 2007.

Gran, G.: Determination of the equivalence point in potentiometric titrations. Part II, Analysis, 77, 661-671, 1952.

Grey, J., Jones, R. I., and Sleep, D.: Seasonal changes in the importance of the source of organic matter to the diet of zooplankton in Loch Ness, as indicated by stable isotope analysis, Limnol. Oceanogr., 46, 505-513, 2001.

Haberyan, K. A. and Hecky, R. E.: The late Pleistocene and Holocene stratigraphy and paleolimnology of Lakes Kivu and Tanganyika, Palaeogeogr. Palaeocl., 61, 169-197, 1987.

Hawley, N. and Lee, C. H.: Sediment resuspension and transport in Lake Michigan during the unstratified period, Sedimentology, 46, 791-805, 1999.

Hecky, R. E. and Kling, H. J.: Phytoplankton ecology of the great lakes in the rift valleys of Central Africa, Arch. Hydrobiol.Beiheft Ergebnisse der Limnologie, 25, 197-228, 1987.

Herczeg, A. L.: A stable carbon isotope study of dissolved inorganic carbon cycling in a softwater lake, Biogeochemistry, 4, 231-263, 1987.

Hollander, D. J. and McKenzie, J. A.: $\mathrm{CO}_{2}$ control on carbonisotope fractionation during aqueous photosynthesis: A paleo$\mathrm{pCO}_{2}$ barometer, Geology, 19, 929-932, 1991.

Jansson, M., Bergström, A. K., Blomqvist, P., and Drakare, S.: Allochthonous organic carbon and phytoplankton/bacterioplankton production relationships in lakes, Ecology, 81, 3250-3255, 2000.

Kaningini, M.: Etude de la croissance, de la reproduction et de l'exploitation de Limnothrissa miodon au lac Kivu, bassin de Bukavu (Zaïre), PhD thesis, Facultés Universitaires Notre Dame de la Paix, Namur, Belgium, 1995.

Kankaala, P., Taipale, S., Grey, J., Sonninen, E., Arvola, L., and Jones, R. I.: Experimental $\delta^{13} \mathrm{C}$ evidence for a contribution of methane to pelagic food webs in lakes, Limnol. Oceanogr., 51, 2821-2827, 2006.

Lehmann, M. F., Bernasconi, S. M., McKenzie, J. A., Barbieri, A., Simona, M., and Veronesi, M.: Seasonal variation of the $\delta^{13} \mathrm{C}$ and $\delta^{15} \mathrm{~N}$ of particulate and dissolved carbon and nitrogen in Lake Lugano: Constraints on biogeochemical cycling in a eutrophic lake, Limnol. Oceanogr., 49, 415-429, 2004.

Lehner, B. and Döll, P.: Development and validation of a global database of lakes, reservoirs and wetlands, J. Hydrol., 296, 1-22, 2004.

Lesutienè, J., Bukaveckas, P. A., Gasiūnaitè, Z. R., Pilkaitytė, R., and Razinkovas-Baziukas, A.: Tracing the isotopic signal of a cyanobacteria bloom through the food web of a Baltic Sea coastal lagoon. Estuar. Coast. Shelf Sci., 138, 47-56, 2014.

Lewis, W. M. J.: Tropical lakes: how latitude makes a difference, in: Perspectives Tropical Limnology, edited by: F. Schiemer and Boland, K. T., SPB Academic Publishing, Amsterdam, 43-64, 1996.

Llirós, M., Gich, F., Plasencia, A., Auguet, J. C., Darchambeau, F., Casamayor, E. O., Descy, J.-P., and Borrego, C.: Vertical distribution of ammonia-oxidizing crenarchaeota and methanogens in the epipelagic waters of Lake Kivu (Rwanda-Democratic Republic of the Congo), Appl. Environ. Microb., 76, 6853-6863, 2010.

Ludwig, W., Probst, J. L., and Kempe, S.: Predicting the oceanic input of organic carbon by continental erosion, Global Biogeochem. Cy., 10, 23-41, 1996.

Macko, S. A., Fogel, M. L., Hare, P. E., and Hoering, T. C.: Isotopic fractionation of nitrogen and carbon in the synthesis of amino acids by microorganisms, Chem. Geol., 65, 79-92, 1987.

Marcé, R., Obrador, B., Morguí, J.-A., Lluís Riera, J., López, P., and Armengol, J.: Carbonate weathering as a driver of $\mathrm{CO}_{2}$ supersaturation in lakes, Nature Geosci., 8, 107-111, 2015.

Masilya, P.: Ecologie alimentaire compare de Limnothrissa miodon et de Lamprichthys tanganicanus au lac Kivu (Afrique de l'Est), $\mathrm{PhD}$ thesis, Facultés Universitaires Notre Dame de la Paix, Namur, Belgium, 2011.

Meyers, P. A. and Eadie, B. J.: Sources, degradation and recycling of organic matter associated with sinking particles in Lake Michigan, Org. Geochem., 20, 47-56, 1993.

Millero, F. J., Graham, T. B., Huang, F., Bustos-Serrano, H., and Pierrot, D.: Dissociation constants of carbonic acid in sea water as a function of salinity and temperature, Mar. Chem., 100, 80 94, 2006.

Montoya, J. P., Carpenter, E. J., and Capone, D. G.: Nitrogen fixation and nitrogen isotope abundances in zooplankton of the oligotrophic North Atlantic, Limnol. Oceanogr., 47, 1617-1628, 2002.

Morana, C., Sarmento, H., Descy, J.-P., Gasol, J. M., Borges, A. V., Bouillon, S., and Darchambeau, F.: Production of dissolved organic matter by phytoplankton and its uptake by heterotrophic prokaryotes in large tropical lakes, Limnol. Oceanogr., 59, 13641375, 2014.

Morana, C., Borges, A. V., Roland, F. A. E., Darchambeau, F., Descy, J.-P., and Bouillon, S.: Methanotrophy within the water column of a large meromictic tropical lake (Lake Kivu, East Africa), Biogeosciences, 12, 2077-2088, doi:10.5194/bg-12-2077-2015, 2015. 
Mugidde, R., Hecky, R. E., Hendzel, L. L., and Taylor, W. D.: Pelagic nitrogen fixation in Lake Victoria (East Africa), J. Great Lakes Res., 29, 76-88, 2003.

Pasche, N., Alunga, G., Mills, K., Muvundja, F., Ryves, D. B., Schurter, M., Wehrli, B., and Schmid, M.: Abrupt onset of carbonate deposition in Lake Kivu during the 1960s: response to recent environmental changes, J. Paleolimnol., 44, 931-946, 2010.

Pasche, N., Schmid, M., Vazquez, F., Schubert, C. J., Wüest, A., Kessler, J. D., Pack, M. A., Reeburgh, W. S., and Bürgmann, H.: Methane sources and sinks in Lake Kivu, J. Geophys. Res., 116, G03006, doi:10.1029/2011JG001690, 2011.

Post, D. M.: Using stable isotopes to estimate trophic position: models, methods, and assumptions, Ecology, 83, 703-718, 2002.

Prairie, Y. T., Bird, D. F., and Cole, J. J.: The summer metabolic balance in the epilimnion of southeastern Quebec lakes, Limnol. Oceanogr., 47, 316-321, 2002.

Sarmento, H.: New paradigms in tropical limnology: the importance of the microbial food web, Hydrobiologia, 686, 1-14, 2012.

Sarmento, H., Isumbisho, M., and Descy, J.-P.: Phytoplankton ecology of Lake Kivu (eastern Africa), J. Plankton Res., 28, 815-829, 2006.

Sarmento, H., Isumbisho, M., Stenuite, S., Darchambeau, F., Leporcq, B., and Descy, J.-P.: Phytoplankton ecology of Lake Kivu (eastern Africa): biomass, production and elemental ratios, Int. Ver. Theor. Angew., 30, 709-713, 2009.

Schelske, C. L. and Hodell, D. A.: Recent changes in productivity and climate of Lake Ontario detected by isotopic analysis of sediments, Limnol. Oceanogr., 36, 961-975, 1991.

Schmid, M., Halbwachs, M., Wehrli, B., and Wüest, A.: Weak mixing in Lake Kivu: new insights indicate increasing risk of uncontrolled gas eruption, Geochem. Geophy. Geosy., 6, Q07009, doi:10.1029/2004GC000892, 2005.

Sirevåg, R., Buchanan, B. B., Berry, J. A., and Troughton, J. H.: Mechanisms of $\mathrm{CO}_{2}$ fixation in bacterial photosynthesis studied by the carbon isotope fractionation technique, Arch. Microbiol., 112, 35-38, 1977.
Sobek, S., Tranvik, L. J., Prairie, Y. T., Kortelainen, P., and Cole, J. J.: Patterns and regulation of dissolved organic carbon: An analysis of 7,500 widely distributed lakes, Limnol. Oceanogr., 52, 1208-1219, 2007.

Stets, E. G., Striegl, R. G., Aiken, G. R., Rosenberry, D. O., and Winter, T. C.: Hydrologic support of carbon dioxide flux revealed by whole-lake carbon budgets, J. Geophys. Res., 114, G01008, doi:10.1029/2008JG000783, 2009.

Thiery, W., Martynov, A., Darchambeau, F., Descy, J.-P., Plisnier, P.-D., Sushama, L., and van Lipzig, N. P. M.: Understanding the performance of the FLake model over two African Great Lakes, Geosci. Model Dev., 7, 317-337, doi:10.5194/gmd-7-317-2014, 2014.

Urban, N. R., Auer, M. T., Green, S. A., Lu, X., Apul, D. S., Powell, K. D., and Bub, L.: Carbon cycling in Lake Superior, J. Geophys. Res.-Oceans, 110, C06S90, doi:10.1029/2003JC002230, 2005.

Wada, E. and Hattori, A.: Natural abundance of ${ }^{15} \mathrm{~N}$ in particulate organic matter in the North Pacific Ocean, Geochim. Cosmochim. Ac., 40, 249-251, 1976.

Weiss, R. F.: Determinations of carbon dioxide and methane by dual catalyst flame ionization chromatography and nitrous oxide by electron capture chromatography, J. Chromatogr. Sci., 19, 611616, 1981.

Weyhenmeyer, G. A. and Karlsson, J.: Nonlinear response of dissolved organic carbon concentrations in boreal lakes to increasing temperatures, Limnol. Oceanogr., 54, 2513-2519, 2009.

Wright, S. W., Jeffrey, S. W., Mantoura, R. F. C., Llewellyn, C. A., Bjornland, T., Repeta, D., and Welschmeyer, N.: Improved HPLC method for the analysis of chlorophylls and carotenoids from marine phytoplankton, Mar. Ecol.-Prog. Ser., 77, 183-196, 1991. 